University of Wollongong

Research Online

Faculty of Business - Papers (Archive)

Faculty of Business and Law

$1-1-2017$

Does big data analytics influence frontline employees in services marketing?

Saradhi Motamarri

University of Wollongong, sm951@uowmail.edu.au

Shahriar Akter

University of Wollongong, sakter@uow.edu.au

Venkata K. Yanamandram

University of Wollongong, venkaty@uow.edu.au

Follow this and additional works at: https://ro.uow.edu.au/buspapers

Part of the Business Commons

Research Online is the open access institutional repository for the University of Wollongong. For further information contact the UOW Library: research-pubs@uow.edu.au 


\title{
Does big data analytics influence frontline employees in services marketing?
}

\author{
Abstract \\ Purpose: Big Data Analytics (BDA) helps service providers with customer insights and competitive \\ information. It also empowers customers with insights about the relative merits of competing services. \\ The paper addresses the research question, "How does big data analytics enable frontline employees \\ (FLEs) in effective service delivery?" \\ Design/methodology/approach: The research develops schemas to visualise service contexts that \\ potentially benefit from BDA, based on the literature drawn from BDA and FLEs streams. Findings: The \\ business drivers for BDA and its level of maturity vary across firms. The primary thrust for BDA is to gain \\ customer insights, resource optimisation and efficient operations. Innovative FLEs operating in \\ knowledge intensive and customisable settings may realise greater value co-creation. \\ Practical implications: There exists a considerable knowledge gap in enabling the FLEs with BDA tools. \\ Managers need to train, orient and empower FLEs to collaborate and create value with customer \\ interactions. Service-Dominant Logic posits that skill asymmetry is the reason for service. So, providers \\ need to enhance skill levels of FLEs continually. Providers also need to focus on market sensing and \\ customer linking abilities of FLEs. \\ Originality/value: Knitting the BDA and FLEs research streams, the paper analyses the impact of BDA on \\ service. The research by contribution service typology portrays its interplay with the typologies of FLEs \\ and BDA. The framework portrays the service contexts in which BD has major impact. Looking further into \\ the future, the discussion raises prominent questions for the discipline.

\section{Disciplines} \\ Business

\section{Publication Details} \\ Motamarri, S., Akter, S. \& Yanamandram, V. K. (2017). Does big data analytics influence frontline \\ employees in services marketing?. Business Process Management Journal, 23 (3), 1-36.
}




\title{
Does Big Data Analytics Influence Frontline Employees in Services Marketing?
}

\begin{abstract}
Purpose: Big Data Analytics (BDA) helps service providers with customer insights and competitive information. It also empowers customers with insights about the relative merits of competing services. The paper addresses the research question, "How does big data analytics enable frontline employees (FLEs) in effective service delivery?"

Research Approach: The research develops schemas to visualise service contexts that potentially benefit from BDA, based on the literature drawn from BDA and FLEs streams.

Findings: The business drivers for BDA and its level of maturity vary across firms. The primary thrust for BDA is to gain customer insights, resource optimisation and efficient operations. Innovative FLEs operating in knowledge intensive and customisable settings may realise greater value co-creation.
\end{abstract}

Implications: There exists a considerable knowledge gap in enabling the FLEs with BDA tools. Managers need to train, orient and empower FLEs to collaborate and create value with customer interactions.

Service-Dominant Logic posits that skill asymmetry is the reason for service. So, providers need to enhance skill levels of FLEs continually. Providers also need to focus on market sensing and customer linking abilities of FLEs.

Both firms and customers need to be aware of privacy and ethical concerns associated with BDA.

Originality/ Value: Knitting the BDA and FLEs research streams, the paper analyses the impact of BDA on service. The research by developing service typology portrays its interplay with the typologies of FLEs and BDA. The framework portrays the service contexts in which $\mathrm{BD}$ has major impact. Looking further into the future, the discussion raises prominent questions for the discipline.

Keywords:

Big Data Analytics (BDA); Frontline Employee (FLE); Service Typology; Frontline Employee Typology; Big Data Maturity Level; Service Adaptation; Service Customisation; Service Delivery; Co-creation. 


\subsection{Introduction}

In service organisations, frontline employees (FLEs) are rightfully referred to as boundary spanners (Bettencourt and Brown, 2003, Bettencourt et al., 2001) because they represent the face of the provider organisation to the customers. The FLEs play a vital role not only in echoing the 'voice of the firm' but also communicating up the managerial layers the 'voice of the customer' (Hauser and Clausing, 1988, Bettencourt et al., 2005). The FLEs are also instrumental in adapting their service to suit the individual customer needs so as to enhance the customer's service experience (Sony and Mekoth, 2014, Di Mascio, 2010, Lai et al., 2014). In high contact services, like financial, healthcare and airlines, FLEs need to deal with every other customer differently as the interactions are highly personal and variable in nature. Detailed information about customers and their path to service facilitate FLEs to adapt the service in an optimal fashion. Recent developments in information and communications technology (ICT) opened up multiple data channels (for example, internet, peer networks, social media, twitter etc.). These channels capture not only transactional data but also a host of associated environmental factors (internet searches, click stream, Facebook chats, Twitter exchanges, peer networking sites etc.) in a granular mode. This data explosion (Demirkan and Delen, 2013, Wielki, 2015a), coupled with the internet of things (IOT), is exponentially multiplying data, leading to the phenomenon called Big Data (BD). Big Data Analytics (BDA) is the capture of data and derivation of insights that act as decisional aids. In the context of services marketing, BDA may imply derivation of insights about customers' preferences and market conditions, which facilitate FLEs to adapt a service to suit the individual customer (Ostrom et al., 2015, Rust and Huang, 2014). For example, for a financial consultant to have a prior idea (Wilder et al., 2014) about a customer beyond transactional data (Cambra-Fierro et al., 2014) will be of excellent value to kick start the discussion with the customer and propose an effective solution; a retailer may well offer better discount to a loyal customer; and an airline may propose a flexible itinerary for a frequent traveller. Aptly, Ostrom et al. (2015) have identified BD as one of the 12 key research priorities for services marketing.

In a way, BDA re-enables the firms to strike a balance between standardisation vs. customisation namely, effectiveness over efficiency, and deliver the service in a much more personalised manner than hitherto possible (Kiron and Shockley, 2011, Vargo and Lusch, 2004). Demirkan and Delen (2013) highlight that in order for BD consisting of customer's online searches or his/her association in discussion groups and other exchanges in social media to be useful, organisations need to overcome the challenges of extracting actionable insights. Axiomatically, BDA can help FLEs in service delivery (Kiron and Shockley, 2011, Kiron et al., 2012), as it lessens service adaptation challenges (Di Mascio, 2010, Sony and Mekoth, 2014). These views about BDA (Dubey et al., 2015, Fosso Wamba et al., 2015, MGI, 2011) and its promise to FLEs (Kiron and Shockley, 2011, Kiron et al., 2012) enabled the authors to undertake a literature search to address the research question:

- How does big data analytics enable frontline employees in effective service delivery?

This research aims to tackle the key challenges encountered by FLEs in BDA, such as how to: (1) enhance service delivery (Ostrom et al., 2015, Rust and Huang, 2014, Lai et al., 2014); (2) facilitate critical support for frontline to adopt and apply BDA (Brown et al., 2014, Barton and Court, 2012); (3) improve frontline to enable mass-customisation (Lai et al., 2014, Rust and Huang, 2014) and (4) build a deeper and lasting relationships with the customers.

The rest of the paper is organised as follows: section two outlines what big data analytics is; section three details research approach, service typology, FLEs and models of FLEs; section 
four draws insights from the literature, presents a schema to visualise the impact of BDA in services context and privacy and ethical issues of BD; section five analyses the impact of BDA on FLEs; section six discusses managerial, theoretical and practical implications of the research; and finally, section seven looks into the limitation of the present work, opportunities for future research and summarises the contributions of this research.

\subsection{What is Big Data Analytics?}

Over the last few years, both practitioners and academics have placed enormous emphasis on BD. According to market analyst firm IDC, the BD and technology services market is growing at the rate of $27 \%$ year on year and in 2017, it will reach US\$ 32.4 billion (Wielki, 2015a). Mahr and Wetzels (2015) predict that investment in BD will explode to US $\$ 125$ billion in 2015. Researchers attribute varying characteristics to BD, such as volume, velocity, variety, value and veracity. The amount of data captured, stored and processed is ever multiplying. In tune, the definition of BD itself is evolving, from $3 \mathrm{Vs}$ to $4 \mathrm{Vs}$ to $5 \mathrm{Vs}$, as summarised below (Fosso Wamba et al., 2015):

5Vs : Volume + Velocity + Variety + Value + Veracity (White, 2012)

4Vs : Volume + Velocity + Variety + Value (IDC, 2012, Oracle, 2012, Forrester, 2012)

3Vs : Volume + Velocity + Variety (Gartner, 2012, Kwon and Sim, 2013, McAfee and Brynjolfsson, 2012)

Synthesising the BD discipline thus far, Fosso Wamba et al. (2015 p.235) define big data "as a holistic approach to manage, process and analyse 5Vs (i.e., volume, variety, velocity, veracity and value) of data." In defining big data analytics, Kiron et al., (2012) develop an integrated focus on statistical, contextual, quantitative, predictive, cognitive, and other aspects of analytics in dealing with BD. This study defines big data analytics as the collection, analysis, visualisation, use and interpretation of data for various functional divisions with a view to gaining actionable insights, creating business value, and establishing competitive advantage. The advancements in virtualisation, in-memory grid computation, large storage arrays, and cheaper computational power (Demirkan and Delen, 2013) have enabled the crunching of this voluminous, heterogeneous, high velocity collection of data in real-time and generating actionable results to the end-users.

While leveraging of BD naturally commences at the top of the command in hierarchy, senior executives are deeply concerned about the little support at the frontline (Brown et al., 2014). Firms need to clearly identify their business drivers for customer relationship management objectives and then strive to cascade them down to the frontline effectively (Beaujean et al., 2006). Those objectives may also influence a firm's service portfolio i.e., the breadth and depth of service offerings. As the initial framework for this current research was in progress, the authors recognised that as services vary broadly from one context to another, the need for, as well as the impact of BDA may vary too. The notion of service typology surfaced after discussion with some services marketing scholars. The services marketing literature widely recognises the vast heterogeneity associated both with services and service delivery (Lai et al., 2014). BDA may be more useful, depending on the context. For example, in a financial advice context, a banker has more opportunity to engage with the customer than in a simple teller service. Owing to these, it is highly relevant to concisely view service typology in this discussion. Thus, the study schema is devised to incorporate service typology as one of the determinants in assessing the impact of BDA on FLEs. This also prompted the possible 
existence of different types of FLEs. As the personal behavioural traits of FLEs are unique in nature, it is also relevant to consider a typology of FLEs (Di Mascio, 2010, Bowen, 2015). In summary, the review aims to blend these relevant streams to draw critical insights to serve as a foundation for future endeavours.

To start with, Figure-1 presents the key focal elements of this research: FLEs, BDA, service typology and customer interactions. The diagram conveys that a firm's customer relationship objectives are reflected in two ways: one, the firm's service portfolio and second, how FLEs are oriented towards customers. Analytic innovator firms (Kiron et al., 2012) cascade the insights of BDA to the FLEs so that they can better serve the customers. The customers too are becoming more insightful through discussion groups, peer networks and publicly shared information on internet (Kilcourse and Rosenblum, 2014). So, a FLE needs to deal with an informed customer, by blending firm objectives, service offerings, differing characteristics of a service (service typology), customer intelligence and customer needs enumerated through the service encounters (Joseph, 1996).

Figure-1: Big Data Analytics, Frontline Employees and Service Encounters

\subsection{Research Approach}

The study is motivated by the impact of big data analytics on frontline employees (Fosso Wamba et al., 2015, Shibata and Kurachi, 2015). In high-interaction oriented service contexts, the FLEs have a significant challenge in facing the customers who are increasingly aware of the market through the multiple information channels (Demirkan and Delen, 2013, Wielki, 2015a). Analogous to typical ICT adoption by users (Delone and McLean, 2003, Venkatesh et al., 2011), cascading big data insights to the frontline, and ensuring FLEs adopt these emerging tools and technologies effectively is a major challenge (Brown et al., 2014). This generic desire to understand how well the new breed of analytical tools enables FLEs in service delivery, has prompted the authors to initiate a literature search. The literature stream pertaining to BD is multiplying every day and a typical search string "big data" gets over 11,000 hits in Scopus and 149,000 hits in Google Scholar. In comparison, a search for "frontline employees" in Scopus produces over a 1,000 hits and in Google Scholar presents over 9,640 results. A systematic approach is needed to scour this voluminous section of articles and identify relevant literature to address our research question.

As the research domain comprises the intersection of multiple literature streams of BD and FLEs, it is logical to look for frontline employees within big data results or vice versa to narrow down the search to a restricted set of articles. The different search strings and the resultant hits are summarised in Appendix-1. As noted above, both BD and FLEs are important areas of research within services marketing literature. However, it is evident from the search results listed in Appendix-1 that the literature seems to be very sparse with respect to $\mathrm{BD}$ in frontline enablement. The results may not be coincidental when it is reckoned with the senior executive concerns about little support at the frontline from BD (Brown et al., 2014) and the formidable challenges of extracting actionable insights from BD (Demirkan and Delen, 2013). 


\subsection{Service Typology}

It is well known that services are generally complex to define and have many dimensions that differentiate one service from the other. A particular service like financial advice delivered to a customer by a financial professional is both time and resource intensive in comparison to withdrawing money from a teller counter. While the former one requires collation and presentation of data in a manner that is relevant to the customer and may require long customer contact time and keen participation of the customer, the withdrawal of money is a less time intensive and requires minimal inputs from the customer. Thus, one can extrapolate that the need of analytics is not a one size fits all (Lai et al., 2014) situation from a service delivery point of view. From the perspective of FLEs, it is further possible to assert that the role and necessity of analytics differ from one service type to another. To differentiate better the service contexts, a service typology is necessary and is developed as shown in Figure- 2 .

While preparing this typology, the seminal ideas of Schmenner (1986) and other studies: (Verma and Boyer, 2000, Glückler and Hammer, 2011, Mills and Margulies, 1980, Bullinger et al., 2003, Prajogo, 2006) are considered. In his paper, Schmenner has used labour intensity and interaction and customisation dimensions to arrive at a $2 \times 2$ service process matrix, forming in all, four service categories. Schmenner termed those services that are low in interaction/labour and customisation as service factory. Highly labour intensive, low interaction and low customisation varieties are termed as mass service. The services that are low in interaction and customisation are referred to as service shops. And finally, at the extreme end of the spectrum where both interaction and customisation are high, are referred to as professional services.

Synthesising the service categorisations of Schmenner (1986) the authors enumerated the dimensions along which a service can be categorised. Figures- $2 \mathrm{a} \& \mathrm{~b}$ portray the identified 13 dimensions for categorising services and they are: channel, customer contact, needs, customisation, service script, relationship, customer input, customer involvement, knowledge intensity, labour intensity, technology intensity, delivery medium and pricing. The advent of $\mathrm{BD}$ and multi-dimensional visualisation techniques help in relatively positioning various services along the dimensional space characterised by the 13 parameters.

The first dimension, channel, differentiates a service whether it is a $\mathrm{B} 2 \mathrm{~B}$ or $\mathrm{B} 2 \mathrm{C}$. The second dimension, customer contact, categorises whether a service involves low or high customer contact. The third dimension, needs, highlights whether the requirements for service are a priori or need to be gathered during the interaction by the FLE. Customisation differentiates whether a service is pre-defined or needs to assemble prior defined service elements. The next dimension, service script, essentially indicates whether the FLE orchestrates routine delivery script or whether the FLE has the flexibility to interact with the customer as s/he tries to understand the customer needs. The relationship dimension helps to define whether a provider treats a service as a mere transaction or wants to build a long term relationship with the customer. This could as well be interpreted from the customer perspective too in a similar manner. Basing on Schemnner's (1986) work, Danaher et al. (2008) segment customers to identify which customers normally like a relationship with the provider.

The customer input dimension differentiates services based on how much information the customer is expected to share with the provider prior to the delivery of a service. The customer involvement dimension differentiates services based on the customer's active involvement, low or high, during service consumption. Knowledge intensity is an important dimension, which highlights whether a service is routine or requires significant professional knowledge from the provider, like a lawyer, engineer or doctor. Similarly, labour intensity 
signifies how laborious a service is for an FLE to deliver. Following the lines of knowledge and labour, technology intensity signifies how dependent a FLE is on technology to deliver the service. The delivery medium, i.e., face-to-face, phone, over internet chat, or asynchronous modes like e-mail, is also an important dimension to be kept in mind. The last dimension, pricing, indirectly indicates how much a FLE is empowered to dynamically alter the pricing for a particular customer in context.

Figure-2a: Service Typology

Figure-2b: Service Typology (contd.)

\subsection{Frontline Employees}

The divergence in the variety of services delivered in the marketplace is a contributing factor to the diversity of names associated with boundary spanners. For example, FLEs are also referred to as frontline staff, frontline personnel, frontline service employees, frontline service staff, customer support, customer support staff, customer service executives, help desk operators, receptionists, service desk employees, service desk consultants and in many more different ways, depending on the country, firm and industry. Our view of FLEs is consistent with those of Zeithaml et al. (2012), who define frontline employees as those at the boundary of a firm, interacting with the customers on behalf of / representing the firm. Firms typically maintain several touchpoints as a form of interaction with their customers. FLEs acting as sensors at several touch points, naturally acquire different names as noted above. In the context of this current study, frontline employees are treated synonymous with all the titles listed above or implied thereof. And in essence, a frontline employee interacts with a customer at one or several touch points.

\subsection{Typology of Frontline Employees}

The above operational definition of FLEs fits a great number of roles. However, to better understand the generic group of FLEs, it is necessary to categorise them. Di Mascio (2010) premises that each FLE is unique in terms of how they deliver their service. This might mean there could be as many service models as there are FLEs. Through an empirical enumeration, Di Mascio (2010) concludes that three distinct service models exist among retail FLEs, namely, efficiency, means and win-win (Di Mascio, 2010 p.67). Firstly, efficiency means the act of giving customers what they ask for, efficiently and courteously; secondly, means conveys a method to accomplishing immediate objectives, such as sales quotas; and finally, win-win reflects the formation of mutually beneficial relationships with customers through problem solving. In contrast to this classification, based on the creative discretions of FLEs during service encounters, Kelly et al. (1996) categorise FLEs into three categories as: creative, routine and deviant discretion.

Coming from a different end of analysis, Bowen (2015) explicitly addresses the evolving position of FLEs, suggests four roles namely: innovators: (technology cannot substitute for 
human creativity as the source of new ideas for services and their delivery); differentiators: (the non-substitutable personal touch avoids the commoditization of service); enablers: (employees, including and understudied back office, ensuring that both customers and technology are able to perform their own roles in coproduction and value creation, overall); and coordinators: (integration of resources and collaboration across multiple actors in the service system).

\subsection{Visualizing the Impact of Big Data Analytics in Services Context}

Scholarly research on BDA can be classified into five themes (Fosso Wamba et al., 2015, Dubey et al., 2015, Steven et al., Forthcoming): decision making and performance improvement, needs identification, creating infrastructure and transparency, new product/business model innovation (Cadwallader et al., 2010, Santos-Vijande et al., 2015) and market segmentation (Fosso Wamba et al., 2015, Shibata and Kurachi, 2015). Fosso Wamba et al. (2015) also observe that a third of the 132 publications they reviewed focus on decision making and performance improvement, revealing the greater interest placed by scholars. The extant literature is predominantly centred on return on investment or monetary value of BDA to the firms rather than on the firm's creation of value with BDA. There exists a wider gap between the importance and the knowledge about BDA (Ostrom et al., 2015), and between the importance and frontline application (Brown et al., 2014, Beaujean et al., 2006). Thus, there is significant opportunity to study how a firm's frontline leverages BDA in adapting service to meet the individual needs of the customers. One of the important insight that emerged from the literature review is that firms need to align their BD programs to strategic goals like improved service delivery and value creation (Wilder et al., 2014, Lavalle, 2009). The strategic decision making and successful cascading of a defined strategy to the frontline determines the success/ failure of a firm as it reflects on the firm's service offerings to capture a profitable segment of the market. BD of a typical firm may consist of several streams of data elements, and thus, its analysis and impact to the firm also has many dimensions. For the success of BDA, firms also require multi-pronged tools like statistical, contextual, quantitative, predictive, cognitive and other models (Kiron et al., 2012). There has been considerable focus on how to go about analysing the BD or understanding the value/ utility of BD (Fosso Wamba et al., 2015). However, there has been lesser emphasis on assessing how BDA enables FLEs and its value creation potential.

Like any other ICT deployments, BD programs cannot happen overnight. Firms need to go through several iterations, before fruitful outcomes are derived and integrated into their service delivery. The starting point to the BD journey may be unique to each firm, but as they progress, they need to develop their programs with the end in mind (Schmarzo, 2012). The storage vendor, EMC provides an interesting framework for the firms to self-evaluate their level of maturity in terms of BD phenomenon as shown in Table-1 (Schmarzo, 2013, Schmarzo, 2012). In contrast to this classification, Kiron et al. (2012) have classified organisations into five distinct levels based on the competitive advantage with analytics and using analytics to innovate. Kiron et al. (2012) referred organisations that are least effective at creating competitive advantage and driving innovation as Level 1, and those organisations that exhibit mastery in the use of analytics both in gaining competitive advantage and for innovation as Level 5. These Level 5 organisations are termed as analytical innovators.

The value of BD comes from the insights it provides (or services it renders) to both service providers and consumers alike (Demirkan and Delen, 2013). The level of insight derived by individual users is not only a function of the BDA climate, but also depends on the structural empowerment of the firm user (Wilder et al., 2014, Bowen and Lawler III, 1992). The 
authors posit that the users need to co-create value through their interactions with the Information System (IS), and possibly with peers, before those insights contribute to improved processing abilities or decision capabilities (Beaujean et al., 2006). While social media platforms like Twitter or Facebook are serving the hedonic needs of consumers, they too are holding valuable information that is of interest to services marketing and FLE's service delivery (Cambra-Fierro et al., 2014). Thus, there has been a surge in both industry and academia to harvest $\mathrm{BD}$ to gain a competitive advantage.

Table-1: Big Data Analytics Maturity Levels; Source (Schmarzo, 2012)

\begin{tabular}{|c|c|c|c|c|}
\hline $\begin{array}{c}\text { Business } \\
\text { Monitoring }\end{array}$ & $\begin{array}{l}\text { Business } \\
\text { Insights }\end{array}$ & $\begin{array}{c}\text { Business } \\
\text { Optimisation }\end{array}$ & $\begin{array}{c}\text { Data } \\
\text { Monetization }\end{array}$ & $\begin{array}{c}\text { Business } \\
\text { Metamorphosis }\end{array}$ \\
\hline $\begin{array}{l}\text { Monitoring } \\
\text { existing } \\
\text { business } \\
\text { performance } \\
\text { using BI to } \\
\text { identify under- } \\
\text { and over- } \\
\text { performing } \\
\text { business areas }\end{array}$ & $\begin{array}{l}\text { Users statistics, } \\
\text { predictive } \\
\text { analytics, and } \\
\text { data mining to } \\
\text { integrate } \\
\text { insights into } \\
\text { existing } \\
\text { business } \\
\text { processes }\end{array}$ & $\begin{array}{l}\text { Embedding } \\
\text { advanced } \\
\text { analytics to } \\
\text { automatically } \\
\text { optimise certain } \\
\text { business } \\
\text { operations }\end{array}$ & $\begin{array}{l}\text { Net new revenue } \\
\text { opportunities: } \\
\text { 1) selling data } \\
\text { with analytics } \\
\text { 2) creating } \\
\text { "intelligent" } \\
\text { products } \\
\text { 3) transforming } \\
\text { customer } \\
\text { relationships }\end{array}$ & $\begin{array}{l}\text { Transform } \\
\text { insights about } \\
\text { customers, } \\
\text { products, and } \\
\text { market trends to } \\
\text { create new } \\
\text { services and/ or } \\
\text { new markets }\end{array}$ \\
\hline
\end{tabular}

Making sense of $\mathrm{BD}$, and visualising connectedness of the underlying business processes through the vast pools of data is a non-trivial task, and goes beyond the mechanical emphasis of tools (Demirkan and Delen, 2013). Mining of data for knowledge extraction has earlier been a dominant concern to Artificial Intelligence Research (Motamarri, 2014). Value derivation from BD is essentially tacit and hermeneutic in nature. While tools of BD tools are important functional aids, the extraction of knowledge/ insights (Kiron, 2015, Chang et al., 2014) is far more complex and hitherto less explored especially from the individual FLE's perspective. Such an exploration contributes new knowledge and understanding of the imperatives of BDA. Furthermore, the exercise can transform BDA as a real value contributor to a firm's sustainable operation.

To map the transient linkages between BDA and FLEs, it is important to answer three distinct questions, namely: 1) what business challenges are driving business intelligence/ business analytics? 2) What are the important uses of the data within a firm context? And 3) How much of the various functional departments of a firm are data driven? The literature search has identified a few interesting publications dealing with some of these aspects (Wielki, 2015a, Kilcourse and Rosenblum, 2014, McKinsey, 2011, NewVantage Partners, 2012, NewVantage Partners, 2014). In all, these works postulate 23 aspects of business drivers/ impacts of BD. Consolidation and summarisation of these drivers emerged to 12 themes as portrayed in Figure-3. The spanning blue boxes reflect the themes emerged out of consolidating business drivers derived from these publications. The labels refer to the research publication as noted in the legend.

Figure-3: Primary Business Drivers/ Important Uses of Big Data 
From Figure-3, it is apparent that firms are still grappling with the emerging phenomena of $\mathrm{BD}$ and that the business drivers or impact of BD varies from firm to firm. The most prominent themes are: 1) business/ customer insights; 2) intelligent application of resources and efficient operations; and followed by 3 ) faster answers to business questions and creation of transparency and data driven culture for decision making. As noted by Kiron et al. (2015, 2012) while $\mathrm{BD}$ has enormous potential to shift organisational power structure to the frontline, a good number of firms are yet to recognise these benefits and equip and empower their FLEs with BDA tools.

\subsection{The Interplay of Service Typology, FLE Typology and BDA Maturity}

The previous sections have proposed a service typology, FLE typology and BDA maturity. These typologies play a vital role in determining the extent to which BDA can impact a service firm. The combination of a service and FLE typologies with varying degrees of BDA maturity create myriad service delivery contexts. Some combinations may have highest possible outcomes both for the provider and the customer, while other contexts may not work out to be differentiators in terms of service outcomes. Figure- 4 illustrates such an attempt to depict the most effective combination where these three typologies intersect and create the highest level of opportunity for the BDA. Using a technique called 'parallel coordinates' for multi-dimensional visualisation (essentially, BD is multi-dimensional), the Figure-4 portrays this most rewarding combination. For the sake of clarity, the diagram doesn't include all the service dimensions. Furthermore, for clarity, the diagram does not indicate all the permutations of connections.

Figure-4, for example, conveys that in the service contexts, where knowledge intensity and customer contact are high, customisation is variable and relationship leans towards collaboration; and FLEs belong to innovators and where BDA in a firm aims for metamorphosis (or Level 5), the resultant value to the firm and customer is exceptional. In parallel coordinates, the connection line thickness is an indicator of the strength of the relationship. For example, four links are culminating at innovators, and thus the link between innovators and business metamorphosis is depicted as four times thicker. The author hypothesises that in order to assess the impact of BDA in service contexts, the typologies of service, FLE and BDA play significant role. Furthermore, firms attempting to leverage BDA need to enhance empowerment and analytic climate (Wilder et al., 2014, Schmarzo, 2013, McKinsey, 2013, Beaujean et al., 2006).

Figure-4: Interplay of Service, FLE Typologies and Big Data Analytics Maturity

\subsection{Big Data: Paradoxes, Privacy and Ethical Issues}

It is also important to recognise some of the downsides of big data revolution. One of the major concerns to BD is privacy of individuals (Brown et al., 2014, Wielki, 2015a, Bollier, 2010) and ethical aspects (Richards and King, 2013, Richards and King, 2014, Davis and Patterson, 2012). Researchers like Bollier and Brown et al. (2014) caution that while big data can benefit consumers, firms and governments with benefits such as improved health-care outcomes, new services, that reflect the consumer preferences and result in valuable digital experience, there are some ethical concerns. Apart from privacy, big data also cuts into the individual's safety to his/her online identity and raises a multitude of ethical questions on who owns the data, who controls it and ultimately whether individuals have any say about 
their personal information (Brown et al., 2014, Bollier, 2010). Another subtle aspect with technology including BDA, is that while it assists service delivery it can also manifest as a barrier during service encounters (Giebelhausen et al., 2014).

The aforementioned discussion drives home that in the current business environment, BD is ubiquitous and its potential for value is very much dependent on an organisation's harvesting abilities (EIU, 2015, MGI, 2011, LCIA, 2011). Benefits apart, there are some formidable ethical and legal challenges with the use of BD. While the collection of BD per se is ethically neutral, the usage is not (Davis and Patterson, 2012, Wielki, 2015b). Fortunately, things are changing with the acceleration of $\mathrm{BD}$, and corporates and end-users started recognising the need for a better data governance model. Data are now recognised as a critical organisational asset as international bodies like World Economic Forum describe 'personal data' as 'new economic asset class' (Davis and Patterson, 2012, EIU, 2015). That being the case, the importance of securing data asset is also increasingly becoming a necessity. Organisations while preparing their BD Strategy need to duly recognise the risks associated with the ongoing collection, securing and usage of BD so that they do not end up in ethical and costly legal battles (Mateosian, 2013).

Coming from a legal perspective, Richards and King (2013) argue that the evangelists claims of the benefits of data driven culture from the minutest tasks of human endeavour to that of medical care are might become true in future but they are anecdotal at the moment. They highlight three paradoxes of big data and caution the public of their consequences. In the view Richards and King (2013) the first one is transparency paradox, for BD consists of pervasive collection of private information and its operation trespasses into legal and commercial secrecy. The second one is identity paradox as $\mathrm{BD}$ promises miraculous outcomes at the expense of individual and collective identity. And the third one is power paradox as BD claims power for the society to transform while in reality only governments and large corporations have the muscle at the expense of ordinary individuals. Richards and King (2013) advise that adopters of BD may gain true value only when they examine these paradoxes in their service contexts and address the issues adequately.

Davis and Patterson (2012) infer that BD's volume, variety and velocity is creating a 'forcing function,' whereby business operations are deeply pushed into the personal lives of people and is altering the common meanings and value implications. Even if the BD removes identification data (de-identify), it is said the simple characteristics of gender, birthdate and zip code allow identification of a person with $87 \%$ of certainty. Thus, Davis and Patterson (2012) warn that though BD creates enormous opportunity for innovation, deeper insights, broader outlooks and better customer engagment, one cannot simply ignore the associated risks, like: security, privacy, legal compliance and customer engagement. Creating meaningful vocabulary and extending these realisations, Davis and Patterson (2012) formulate the four aspects associated with BD Ethics as: identify, privacy, ownership and reputation. They also identify certain ethical incoherence within the value framework of the Fortune 50 companies itself, and suggests that it is time to reconcile and create a coherent policy. They further propose a continuous cycle for ethical decision points: inquiry, understanding, articulation and action. Davis and Patterson (2012) in conclusion urges organisations to adopt transparent BD Governance policies to clearly address the questions whether the current practices align with their own core values and customer's values. Inspired by these valuable arguments, the authors urge academic scholars, organisations and practitioners not to undervalue the associated risk factors of BD in advocating $\mathrm{BD}$ for economic leverage. Mateosian (2013 p.61) warns that "[b]ig data is coming like a runaway 
freight train, and we must methodically examine the issues and take appropriate actions, or we won't like the mess it makes when it crashes."

\subsection{Impact of Big Data Analytics on Frontline Employees: Challenges and Opportunities}

Prior to analysing how BD may have a positive impact on the roles of FLEs, it is worthwhile to look into the demands FLEs succumb in facing customers and delivering the marketing promises. Zeithaml et al. (2012) argue that irrespective of the skill or pay, the boundary spanning roles cause high-stress due to the demands on emotional labour and mental and physical needs. FLEs are frequently confronted with irate customers and need to deal with both intra-organisational as well as inter-organisational or organisation vs. customer conflicts (Browning, 2008, Gruber, 2011, Kashif and Zarkada, 2015, Reynolds and Harris, 2006). FLE's job performance may also be impacted and become stressful due to organisational factors, training, inadequate resources, lack of recognition, pressure to exceed targets and inadequate tools to perform the job meeting the quality expectations (Oh et al., 2014, Devi and Sharma, 2013, Dean and Rainnie, 2009). FLEs may need to react to situations in real time and require to trade-off between quality and productivity of the work. Zeithaml et al. (2012) further reflect that these stresses may contribute to service delivery failures and thus contribute to performance gap.

FLEs are not always be able to accommodate and adjust the system to meet the requirements of internal as well as external customers alike, causing dissatisfaction at both ends (Zeithaml et al., 2012). Sony and Mekoth (2012) observe that FLEs need to adopt to situational factors and actively draw information from situational cues and adapt their service on the basis of the information drawn. In such situations, the better the FLEs can gauge the customers' needs and behavioural profiles, the better they can serve them.

\subsection{Big Data Analytics: Business Challenges to Service Industry}

Retail Systems Research (RSR) organisation has conducted extensive study with its constituent retail industry members on BD. The survey identified the significant business challenges for BD adoption. The top five drivers identified are (Kilcourse and Rosenblum, 2014 p.6): one, consumers expect instantaneous access to information; second, consumers 'path to purchase' (a dynamic, consumer journey that moves from customer's initial awareness to pre-purchase, purchase and advocacy stages in a multi-channel environment); three, information -empowered customers are demanding more; four, firms need to react to sudden changes in customer demands; and five, the necessity for constructing alternative scenarios to cope up with market dynamism.

RSR researchers have also identified that the retail winners are leading in the first four items over the laggards. However, for item five, the laggards have a higher score. With this they conclude: "[r]etail winners understand that consumers are demanding, expect full access to information about products and services wherever they may be, and that these same consumers can be fickle, rapid and radical changes in trends and demands are expected and lag-time to action must be decreased. Laggards on the other hand are perennially focused on their competitors. ... Winners look within or to the customers, laggards look over their shoulders" (Kilcourse and Rosenblum, 2014 p.6-7).

From these assessments, it is apparent that FLEs constantly face more informed customers who demand a quicker and optimal solution tailored to them. While some of the successful companies are leveraging $\mathrm{BD}$, there are far more firms that are yet to recognise the value of 
customer relationship over imitating the competition (Kiron et al., 2012). Reinforcing these ideas, Harvard Business Analytics Services team reflects that frontline managers do not get adequate representation and they are not equipped with the right $\mathrm{BD}$ tools to enable them serve better (HBR, 2014). The HBR study asserts that while organisations recognise frontline managers as linchpin for organisational success, that recognition however, does not translate into giving them the requisite resources, adversely affecting firm performance. At again, the firm-customer relationship must happen through the frontline as sometimes FLEs are themselves equated to the service they deliver (Zeithaml et al., 2012). So, it is imperative for the firms to percolate/ grant access to the strategic customer insights from BD, so that FLEs serve the customers in an effective manner.

In high contact services, standardisation may not work as each customer context is different (Lai et al., 2014). Though, technology enhances service delivery, it can also become a barrier for rapport building, meaning BD tools shall not hinder the creative process of the FLEs on one hand and the comfort of the customers on the other hand (Giebelhausen et al., 2014). FLEs need to innovate during the service encounter, so they better serve the customer (Lai et al., 2014, Moosa and Panurach, 2008). Moosa and Panurach also contend that centralised innovation is not only insufficient but also ineffective. Being at the forefront of service delivery, FLEs have much more experience, but their voice is not accounted for in a firm's strategic roadmap (Moosa and Panurach, 2008). FLEs need tools and better information. BDA has a great potential to serve such innovation needs of FLEs by virtue of providing deeper insights on what the customer actually needs and his/her set of preferences (CambraFierro et al., 2014). Building on these insights, the next sub-section enumerates how BDA can be an enabler to services marketing.

\subsection{Big Data Analytics: An Enabler for Services Marketing}

The following enumeration will look into how some service marketing imperatives can be addressed by BDA. The challenge however is to strike a balance between customers' desire for privacy and personalised services. BDA has a big promise; however, there are formidable implementation challenges. Shibata and Kurachi (2015) categorise them as: 1) difficulty of introducing new technologies; 2) difficulty of defining system requirements; and 3) difficulty of estimating effects of implementation. Service firms need to be aware of these issues and make a systematic contingency plan prior to embarking on BD programs. The following scenarios highlight the ways in which BDA helps in dealing with changing service situations.

1) Dynamically manage customer value over time: BDA provides firm-customer relationship, customer satisfaction information, as well as customer pain points with the firm and firm's service offerings. Service providers are able to link customer complaints, word of mouth campaign (blogs, peer networks, social media exchanges etc.) so that the FLEs are aware of the customer concerns. This enables them to empathise with the customer situation and offer amenable solutions (Wilder et al., 2014) to increase customer value over time.

2) Improve the customer experience and customer-firm relationships: FLEs are notified through BDA the kind of products/ services the customer is looking for and customer's past purchasing history. Shibata and Kurachi (2015 p.39) describes a case where "store management increased sales due to optimising the floor layout and enhancing customer interaction through customer behaviour analysis."

3) Personalise service dynamically and in real-time: FLEs ability to personalise the product/ service to make them develop brand loyalty. The authors came across that 
some of the financial institutions are pre-alerting their planners the internet searches and click stream data associated with a prospective customer. The information enables the planner to be aware of what the customer had already viewed and gauge what the customer may be looking for.

4) Uncover opportunities for service innovation and create new service offerings: FLEs ability to assess strategic gaps between existing service offerings and customer needs, and dynamically ensemble service elements to customise the service to the customer. As noted in the beginning of this paper FLEs are also critical in reflecting the voice of the customer (Hauser and Clausing, 1988) to the strategic planning teams, enabling them to devise new service offerings.

5) Assist in real-time decision making: up to date information about customer's online searches for specific services; customer's feedback on services consumed. Similar to points 2 and 8 . For example, a hotel amending the breakfast choices to guests based on the feedback received.

6) Customise: customising a service offering as per the needs of the customer. Shibata and Kurachi (2015 p.35) describe that “... this company has been able to increase sales by switching product promotion to low-calorie drinks popular among women on the day of a concert that a large number of women are expected to attend. This is a case study of a frontline department that has achieved micromarketing and expanded business by introducing a big-data analysis environment."

7) Undertake Predictive modelling: ability to forecast future purchases of the customer. Shibata and Kurachi (2015 p.35) describe that "sales staff at a beverage manufacturer can now perform detailed promotions at each sales outlet in their area through demand forecasting that takes into account not just detailed sales data from those retail stores but also external data such as regional weather and events."

8) Deliver dynamic pricing: ability of FLEs to visualise customer's historical spending, competitive choices and fine tuning pricing. The authors came across solutions based on big data presentation tools like Tableau targeted to help sales personnel to offer special discounts for repeat customers as well as to win a share of the customer wallet by not letting them switch to a competitor.

9) Segmentation: categorising customers into groups that enable FLEs to visualise best possible solution for a customer. Shibata and Kurachi (2015) describe that customer behaviour analysis model combines conventional purchasing data with external information from FLEs and social networks.

10) Campaign management: advertisement campaign management based on customer's preferences about location, medium, timing and gender. Shibata and Kurachi (2015) describe that while conventional mass marketing is based on wholesale shipping data, BDA solution supports micromarketing approach in accordance to demand forecasting.

11) Supply chain or operational effectiveness: Shibata and Kurachi (2015 p.39) describe that "optimised inventory due to increasing the accuracy of demand forecasting (reduce out-of-stock losses and decrease waste)." 
12) Manage service design: continual customer-firm interactions across the touchpoints that help to move away from static design of service to one that is evolving, iterative and personalised (Erickson, 2009, Ostrom et al., 2015, Rust and Huang, 2014).

\subsection{Discussion}

\subsection{Managerial Implications}

Rust and Huang (2014) conclude that information revolution and service revolution are two sides of the same coin. Interestingly, analysing the socio-technical systems and servicedominant logic, Motamarri (2015) comes to a similar conclusion. Ostrom et al. (2015 p.127), basing on the propositions of Rust and Huang (2014) summarise that: "...rapidly evolving information technologies (e.g., Internet of Things, social network technology, mobile technology and cloud computing) enable ubiquitous customer communication and the acquisition, storage and analysis of big data, presenting opportunities for more personalized, higher quality service, and deeper customer relationships." In their detailed assessment on service research priorities in the rapidly changing context, Ostrom et al. (2015) stress that BD has a significant role in advancing service. In essence, BD to advance service is one of the 12 research priorities identified by them. Considering the massive drive towards $\mathrm{BD}$ in the industry (Fosso Wamba et al., 2015, Brown et al., 2014), it is quite natural for the service research to focus on $\mathrm{BD}$ so as to be relevant both for theory and practice.

Ostrom et al. (2015) summarise that the theme using BD to advance service, has the widest gap between the importance and the knowledge ratings. This implies a fertile service research opportunity and calls for building new knowledge pertaining to this domain. Ostrom et al. (2015 p.137) have identified seven subtopics, out of which four of them centre around BDA and FLEs as noted below: one, using BD to dynamically manage customer value over time; two, understanding conflicts between customer's desire for privacy and their desire for personalized service; three, using BD to improve customer experience and customer-firm relationships; and four, developing analytic and recommendation models for dynamic and real-time service personalization.

The McKinsey team, Brown et al. (2014), probed a group of frontline executives responsible for data-analytics revolution across different industries. They conclude that BDA is delivering value at strategic level, but not to the FLEs. Decision makers perceive that making the frontline adopt and use BDA tools effectively as a major challenge (Brown et al., 2014). The Harvard Business Review team asserts that lack of adequate training, resources and BD tools for frontline managers is hindering firm performance (HBR, 2014). To bridge this implementation gap, the Harvard team stresses that senior managers need to eliminate barriers that hinder progress as well as impact performance of frontline. This is an important input to managers as it demonstrates time and again that recognition of the importance of frontline is not adequate; firms need to move forward and train and equip the frontline so that they can serve the firms in a better way.

It is worth recalling another major research theme, enhancing the service experience, illustrated by Ostrom et al. (2015). They have deduced seven major issues. BDA has the ability to address all these issues. It enables the FLEs to gauge customer service experience attributes inferred through the service encounters across the touch points and channels. FLEs will be able to dynamically structure service delivery to match the expectations of the customers. Huang and Rust (2014) contend that mass customisation of service by FLEs is feasible as BD provides granular customer information which facilitates segmentation of 
customers as well as helps to fine tune the service. Similar to the notion of standardised service may not fit all customers; standardised training in BDA may not be sufficient to all FLEs. The managers need to focus on the service contexts at the interplay of Service Typology and FLE Typology (Di Mascio, 2010) to design customised training programs to equip the FLEs to achieve firm objectives.

\subsection{Implications to Theory and Practice}

This study provides the foundation for extending the Service-Dominant Logic (SDL) which views that technological progression results in greater skill-differentiation (Vargo and Lusch, 2004). The skill-asymmetry between the provider and customer is the fundamental reason for the service economy. It transiently conveys a retrograde from service standardisation (an aftermath of Industrial Revolution) to service differentiation. Though Vargo and Lusch $(2004,2008)$ have not directly indicated it, the skill-asymmetry also implies that service firms need to enhance their knowledge and skill-sets of their resources (put together, operant resources) continually, in order to compete for their pie in the market. As service contexts become dynamic and the customers take greater role in value-creation, it is imperative that firms leverage BDA to ensure that their FLEs adapt services and serve customers well. An empowered FLE with due access to the insights about the prospective customers, can potentially adapt the service delivery with a priori information. In essence, the current research focus on FLEs asserts that there is tremendous opportunity to understand and value the contributions of the frontline. Furthermore, FLEs service adaptability enables to assess not only their value creation through service encounters, but also the generic enhancement of the firm's operant resources, thus competitiveness.

The findings of our study are also relevant to service adaptation theory. For example, Wilder et al., (2014) discuss that customers are expecting individual customisation in contrast to conventional efficiency drives. Wilder et al. further hypothesise that a FLE's capacity to anticipate customers' feelings, motives and concerns shall aid in service customisation and thus enhance customer experience. As eventually service is delivered by the FLEs, firms have an implicit challenge to strive for skill asymmetry between their frontline and customers. Firms can achieve this by keeping their frontline abreast of the information that enables them to serve the customers better. Thus, BDA has a significant role in preparing FLEs prior to/during the service encounters with significant information about the customers they are servicing. The authors imply that the skill asymmetry is the counter force for the customisation demands of the customers. Thus, organisations setting aside the personality traits of FLEs, can promote adaptability capacities of FLEs (Wilder et al., 2014) by providing them training as well as granting access to insightful information (Fang et al., 2014). The insights help FLEs in two ways: first, identification of customisation opportunities for the specific customer they are servicing and second, determination of how they can adapt the service to suit to this customer (Wilder et al., 2014).

Through their empirical research, Wilder et, al. (2014) validated that while empathy and anticipation helps in customisation opportunity, FLEs creativity demonstrates their actual ability to adapt a service. This argument is also supported by Bowen and Lawler III (1992). While discussing empowerment of FLEs, they address the basic questions of empowerment, like: what, why, how and when. In essence, a firm's service climate and empowerment found to be positively related to the FLEs ability to adapt service to the needs of the customers (Bowen and Lawler III, 1992, Wilder et al., 2014). In addition to SDL and service adaptation theories, our research provides necessary platform for advancing market orientation theory. For example, firms that concentrate on market orientation structure their activities to create superior value for their customers (Fang et al., 2014). Market orientation can be understood 
in two parts: Internal Market Orientation (IMO) and External Marketing Capability (EMC) (Fang et al., 2014). Fang et al. (2014 p.172) refer IMO as "the process of generating and disseminating intelligence about internal market needs and then responding to and satisfying these needs." Market oriented organisations concentrate on market-sensing and customerlinking to signify their EMC. Fang et al. (2014 p.173) define market-sensing as "an organisation's capability of learning market knowledge and utilising this knowledge in forecasting the future market development." Fang et al. (2014 p.173) further define customerlinking capability as "an organisation's capability of effectively establishing and maintaining appropriate customer relationships after the organisation identifies and understands its target customer's needs." BDA by virtue of capturing and synthesising granular information about customers they significantly contribute to EMC of a firm.

From the relational paradigm perspective, continual firm-to-customer interactions and customer-to-customer co-learning affect non-transactional behaviour of customers (CambraFierro et al., 2014). Some of these interactions are voluntary, and may not translate to immediate sales, but in the long run, improves company image and future purchase decisions of consumers (Cambra-Fierro et al., 2014). BDA provides an opportunity to capture, process and present such interactional information from social media to frontline, so that they can fine-tune delivery patterns to influence the customer engagement.

Following these observations, the authors deduce that BDA climate, empowerment of the FLEs in combination with the FLEs skills of market sensing, and customer linking abilities will positively influence service delivery. As firms derive market/ customer insights from BDA (Figure-3), it is imperative that firms focus on creating a transparent data driven culture, be innovators in BDA, and empower the FLEs with right information and tools, so that FLEs will succeed in delivering the marketing promise of the firms.

From the perspective of practice, BDA may yield greater benefits in high contact service contexts. A win-win style of FLEs over other types (Di Mascio, 2010), may leverage BDA to deliver value both to the customers and firms. Managers also need to recognise that a firm's BDA maturity and strategy (Schmarzo, 2012, Schmarzo, 2013, Kiron and Shockley, 2011) will have significant impact on the frontline so that greater value is derived from each service encounter. Managers need to focus on training FLEs with market orientation and customer linking and improve the BDA climate to generate greater benefits for the firm, the customer and the FLEs (Wilder et al., 2014).

\subsection{Conclusions and Future Agenda}

\subsection{Limitations}

The aim of this research is to understand how well firms are leveraging BDA in enabling the frontline to serve customers better. As an auxiliary, the research also intended to uncover how BDA enables FLEs in service customisation and adaptation to suit individual customers. However, the search within the extant literature has not pointed to any relevant scholarly work, except the tools being developed and marketed by Fujitsu (Shibata and Kurachi, 2015).

This does not seem to be surprising as evinced from the panel discussion (consisting of experts both from academia and industry) on big data analytics' relevance to marketing at the Australia New Zealand Marketing Academy Conference (ANZMAC 2015) held on 30-Nov2015 in Sydney. The panel is of the opinion that there is tremendous opportunity for marketing to leverage $\mathrm{BD}$ but the progress seems to be rather slow. It is also opined that the 
chances of new product/ service development out of BD is very difficult for the fact that human innovative spirit cannot easily be mimicked by sophisticated information systems, i.e., Artificial Intelligence tools (Demirkan and Delen, 2013).

\subsection{Future Research Agenda}

The authors are of the opinion that the service firms may be at different stages along the big data adoption cycle (Table-1), and it is plausible that firms may be placing significant focus on building the infrastructure rather than deeply looking into the program to ensure that the investments have a direct impact on the frontline (McKinsey, 2011, Kilcourse and Rosenblum, 2014). Similar opinion is expressed by the panel of experts at ANZMAC 2015.

The BDA is touted to revolutionise the business world. The extant literature too is predominantly anecdotal. Given this context, the authors are confronted with the following broad questions to drive the future research agenda: 1) what specific insights are derived from big data by firms about customer preferences and service delivery? 2) How do firms utilise those insights? (For example, improving service/ service portfolio; what information is cascaded to frontline so that they can serve better; and does frontline staff distinguish cascaded information as big data?) 3) Do frontline employees have a direct access to big data? (If so, what sort of information? And do frontline staff run analytic queries, test models or just use information pushed down to them?); and 4) do big data insights empower frontline employees in linking customers and improving firm performance?

As there is a significant knowledge gap on these broad issues in the extant literature, the authors intend to take up a further study with major service firms like banks, airlines or healthcare providers. It is anticipated that a qualitative field study will help to portray the maturity of BDA and its influencing role on the frontline. Having synthesised the services context, the authors intend to develop a survey instrument to collect data from different industries and build a quantitative model to serve predictive purposes. Such empirical work while producing quantitative evidence to the premise would also benefit both management and practitioners alike. The future work shall focus on develop a robust plan, so that firms are set to realise benefits from big data in enhancing their service delivery, and creating meaningful positive impact to the client organisation.

\subsection{Conclusions}

Service, which is more of personal in nature (Vargo and Lusch, 2004), has succumbed to standardisation. Coupled with the transformative changes of service revolution (Rust and Huang, 2014), BDA is re-enabling the firms to balance standardisation vs. customisation challenges viz., effectiveness vs. efficiency (Kiron and Shockley, 2011). BDA contributes to not only transparency and data-driven decision making (NewVantage Partners, 2014) but also shifting the power to downstream, i.e., FLEs (Kiron et al., 2012). Following the empirical works of (Wilder et al., 2014, Sony and Mekoth, 2014) the authors are motivated to find how well BDA is enabling the FLEs in service adaptation. Our literature search pointed out that there is a significant gap in literature about FLEs within BDA or vice versa. This research fills that knowledge gap by bridging the streams of FLEs and BDA. 


\section{References}

BARTON, D. \& COURT, D. 2012. Making advanced analytics work for you. Harvard business review, 90, 78-83, 128.

BEAUJEAN, M., DAVIDSON, J. \& MADGE, S. 2006. The 'moment of truth' in customer service. The McKinsey Quarterly.

BETTENCOURT, L. A. \& BROWN, S. W. 2003. Role Stressors and Customer-Oriented BoundarySpanning Behaviors in Service Organizations. Journal of the Academy of Marketing Science, 31, 394-408.

BETTENCOURT, L. A., BROWN, S. W. \& MACKENZIE, S. B. 2005. Customer-oriented boundaryspanning behaviors: Test of a social exchange model of antecedents. Journal of Retailing, 81, 141-157.

BETTENCOURT, L. A., GWINNER, K. P. \& MEUTER, M. L. 2001. A comparison of attitude, personality, and knowledge predictors of service-oriented organizational citizenship behaviors. Journal of Applied Psychology, 86, 29-41.

BOLLIER, D. 2010. The Promise and Peril of Big Data. Washington, DC: The Aspen Institute.

BOWEN, D. E. 2015. The changing role of employees in service theory and practice: An interdisciplinary view. Human Resource Management Review.

BOWEN, D. E. \& LAWLER III, E. E. 1992. The empowerment of service workers: what, why, how, and when. Sloan management review, 33, 31-39.

BROWN, B., COURT, D. \& MCGUIRE, T. 2014. Views from the front lines of the data-analytics revolution. McKinsey Quarterly.

BROWNING, V. 2008. An exploratory study into deviant behaviour in the service encounter: How and why front-line employees engage in deviant behaviour. Journal of Management \& Organization, 14, 451-471.

BULLINGER, H.-J., FÄHNRICH, K.-P. \& MEIREN, T. 2003. Service engineering-methodical development of new service products. International Journal of Production Economics, 85, 275-287.

CADWALLADER, S., JARVIS, C. B., BITNER, M. J. \& OSTROM, A. L. 2010. Frontline employee motivation to participate in service innovation implementation. Journal of the Academy of Marketing Science, 38, 219-239.

CAMBRA-FIERRO, J., MELERO-POLO, I. \& VÁZQUEZ-CARRASCO, R. 2014. The role of frontline employees in customer engagement. Revista Española de Investigación en Marketing ESIC, 18, 67-77.

CHANG, R. M., KAUFFMAN, R. J. \& KWON, Y. 2014. Understanding the paradigm shift to computational social science in the presence of big data. Decision Support Systems, 63, 6780.

DANAHER, P. J., CONROY, D. M. \& MCCOLL-KENNEDY, J. R. 2008. Who Wants a Relationship Anyway?: Conditions When Consumers Expect a Relationship With Their Service Provider. Journal of Service Research, 11, 43-62.

DAVIS, K. \& PATTERSON, D. 2012. Ethics of big data, Sebastopol, Calif. : O'Reilly, 2012.

DEAN, A. M. \& RAINNIE, A. 2009. Frontline employees' views on organizational factors that affect the delivery of service quality in call centers. Journal of Services Marketing, 23, 326-337.

DELONE, W. H. \& MCLEAN, E. R. 2003. The DeLone and McLean Model of Information Systems Success: A Ten-Year Update. Journal of Management Information Systems, 19, 9-30.

DEMIRKAN, H. \& DELEN, D. 2013. Leveraging the capabilities of service-oriented decision support systems: Putting analytics and big data in cloud. Decision Support Systems, 55, 412-421.

DEVI, A. \& SHARMA, J. 2013. Investigating role stress in frontline bank employees: A cluster based approach. IIMB Management Review, 25, 171-178.

DI MASCIO, R. 2010. The Service Models of Frontline Employees. Journal of Marketing, 74, 63-80. 
DUBEY, R., GUNASEKARAN, A., CHILDE, S. J., FOSSO WAMBA, S. \& PAPADOPOULOS, T. 2015. The impact of big data on world-class sustainable manufacturing. International Journal of Advanced Manufacturing Technology.

EIU, T. E. I. U. 2015. Big data evolution: Forging new corporate capabilities for the long term. London, UK: The Economist Intelligence Unit sponsored by SAS.

ERICKSON, T. 2009. Socio-Technical Design. In: WHITWORTH, B. \& DE, M. A. (eds.) Handbook of Research on Socio-Technical Design and Social Networking Systems. New York: Information Science Research (IGI Global).

FANG, S. R., CHANG, E., OU, C. C. \& CHOU, C. H. 2014. Internal market orientation, market capabilities and learning orientation. European Journal of Marketing, 48, 170-192.

FORRESTER 2012. The Big Deal About Big Data For Customer Engagement Business: Leaders Must Lead Big Data Initiatives To Derive Value.

FOSSO WAMBA, S., AKTER, S., EDWARDS, A., CHOPIN, G. \& GNANZOU, D. 2015. How 'big data' can make big impact: Findings from a systematic review and a longitudinal case study. International Journal of Production Economics, 165, 234-246.

GARTNER. 2012. Big Data [Online]. Gartner. Available: http://www.gartner.com/it-glossary/big-data [Accessed 17-Mar 2016].

GIEBELHAUSEN, M., ROBINSON, S. G., SIRIANNI, N. J. \& BRADY, M. K. 2014. Touch Versus Tech: When technology functions as a barrier or a benefit to service encounters. Journal of Marketing, 78, 113-124.

GLÜCKLER, J. \& HAMMER, I. 2011. A pragmatic service typology: capturing the distinctive dynamics of services in time and space. The Service Industries Journal, 31, 941-957.

GRUBER, T. 2011. I want to believe they really care How complaining customers want to be treated by frontline employees. Journal of Service Management, 22, 85-110.

HAUSER, J. R. \& CLAUSING, D. 1988. The House of Quality. Harvard Business Review.

HBR, H. B. R. 2014. Frontline Managers: Are They Given the Leadership Tools to Succeed. Harvard Business School Analytic Services.

IDC 2012. The Digital Universe in 2020: Big Data, Bigger Digital Shadows, and Biggest Growth in the Far East.

JOSEPH, W. B. 1996. Internal marketing builds service quality. Journal of Health Care Marketing, 16, 54-59.

KASHIF, M. \& ZARKADA, A. 2015. Value co-destruction between customers and frontline employees: A social system perspective. International Journal of Bank Marketing, 33, 672-691.

KELLEY, S. W., LONGFELLOW, T. \& MALEHORN, J. 1996. Organizational determinants of service employees' exercise of routine, creative, and deviant discretion. Journal of Retailing, 72, 135-157.

KILCOURSE, B. \& ROSENBLUM, P. 2014. Retail Analytics Moves To The Frontline. USA: Retail Systems Research.

KIRON, D. 2015. Innovating with Airborne Analytics: Joe Locandro (Cathay Pacific) Interviewed by David Kiron. MIT Sloan Management Review, Reprint \#57107.

KIRON, D., KIRK PRENTICE, P. \& FERGUSON, R. B. 2012. Innovating With Analytics. MIT Sloan Management Review, 54, 47-51.

KIRON, D. \& SHOCKLEY, R. 2011. Creating business value with analytics. MIT Sloan Management Review, 53, 57-63.

KWON, O. \& SIM, J. M. 2013. Effects of data set features on the performances of classification algorithms. Expert Systems with Applications, 40, 1847-1857.

LAI, J., LUI, S. S. \& HON, A. H. Y. 2014. Does standardized service fit all?: Novel service encounter in frontline employee-customer interface. International Journal of Contemporary Hospitality Management, 26, 1341-1363.

LAVALLE, S. 2009. Business Analytics and Optimization for the Intelligent Enterprise. 
LCIA, L. C. F. I. A. 2011. Big Data: Big Opportunities to Create Business Value. Hopkinton, MA: LCIA, EMC Corporation.

MAHR, D. \& WETZELS, M. 27-Sep-2015 2015. Big Data = Big Service Research? http://www.servsig.org/wordpress/2015/09/big-data-big-service-research/ [Online]. Available from: http://www.servsig.org/wordpress/2015/09/big-data-big-service-research/ [Accessed 02-Oct-2015 2015].

MATEOSIAN, R. 2013. Ethics of Big Data. Micro, IEEE, 33, 60-61.

MCAFEE, A. \& BRYNJOLFSSON, E. 2012. Big Data. Harvard Bus Rev, 90, 61-67.

MCKINSEY 2013. The 'big data' revolution in healthcare: Accelerating value and innovation.

MCKINSEY, M. G. I. 2011. Big data: The next frontier for innovation, competition, and productivity. McKinsey Global Institute.

MGI, M. G. I. 2011. Big Data: The frontier for innovation, competition, and productivity. USA: McKinsey Global Institute.

MILLS, P. K. \& MARGULIES, N. 1980. Toward a core typology of service organizations. Academy of Management. The Academy of Management Review (pre-1986), 5, 255.

MOOSA, N. \& PANURACH, P. 2008. Encouraging front-line employees to rise to the innovation challenge. Strategy and Leadership, 36, 4-9.

MOTAMARRI, S. 2014. Reflections on Artificial Intelligence - A Hermeneutic Journey. The 25th Australasian Conference on Information Systems. Auckland University of Technology, Auckland, New Zealand: ACIS.

NEWVANTAGE PARTNERS. 2012. Big Data Executive Survey: Creating a Big Data Environment to Accelerate Business Value [Online]. NewVantage Partners LLC. Available: http://newvantage.com/wp-content/uploads/2012/12/NVP-Big-Data-Survey-AccelerateBusiness-Value.pdf [Accessed 03-Dec-2015 2015].

NEWVANTAGE PARTNERS. 2014. Big Data Executive Survey 2014: An Update on the Progress of Big Data in the Large Corporate World [Online]. Boston: NewVantage Partners LLC. Available: http://newvantage.com/wp-content/uploads/2014/12/Big-Data-Survey-2014-SummaryReport-110314.pdf [Accessed 02-Dec-2015 2015].

$\mathrm{OH}$, J. H., PARK, J. \& RUTHERFORD, B. N. 2014. Management of frontline financial sales personnel. Journal of Financial Services Marketing, 19, 208-220.

ORACLE 2012. Big Data for the Enterprise.

OSTROM, A. L., PARASURAMAN, A., BOWEN, D. E., PATRíCIO, L. \& VOSS, C. A. 2015. Service Research Priorities in a Rapidly Changing Context. Journal of Service Research, 18, 127-159.

PRAJOGO, D. 2006. The implementation of operations management techniques in service organisations: An Australian perspective. International Journal of Operations \& Production Management, 26, 1374-1390.

REYNOLDS, K. L. \& HARRIS, L. C. 2006. Deviant customer behavior: An exploration of frontline employee tactics. Journal of Marketing Theory and Practice, 14, 95-111.

RICHARDS, N. M. \& KING, J. H. 2013. Three Paradoxes of Big Data. Stanford Law Review Online, 41, 41-46.

RICHARDS, N. M. \& KING, J. H. 2014. Big Data Ethics. Wake Forest Law Review, 49, 393:432.

RUST, R. T. \& HUANG, M. H. 2014. The service revolution and the transformation of marketing science. Marketing Science, 33, 206-221.

SANTOS-VIJANDE, M. L., LÓPEZ-SÁNCHEZ, J. Á. \& RUDD, J. 2015. Frontline employees' collaboration in industrial service innovation: routes of co-creation's effects on new service performance. Journal of the Academy of Marketing Science.

SCHMARZO, B. 2012. Big Data Business Model Maturity Chart [Online]. www.emc.com. Available: https://infocus.emc.com/william schmarzo/big-data-business-model-maturity-chart/ [Accessed 03-Dec-2015 2015]. 
SCHMARZO, B. 2013. Big Data Business Maturity Index [Online]. EMC. Available: https://infocus.emc.com/william schmarzo/learnings-from-the-field/ [Accessed 03-Dec2015 2015].

SCHMENNER, R. W. 1986. How can service businesses survive and prosper? Sloan management review, 27, 21-32.

SHIBATA, T. \& KURACHI, Y. 2015. Big data analysis solutions for driving innovation in on-site decision making. Fujitsu Scientific and Technical Journal, 51, 33-41.

SONY, M. \& MEKOTH, N. 2012. A typology for frontline employee adaptability to gain insights in service customisation: A viewpoint. International Journal of Services and Operations Management, 12, 490-508.

SONY, M. \& MEKOTH, N. 2014. FLE adaptability in high contact and high customisable services: Theoretical underpinnings and conceptual model. International Journal of Services and Operations Management, 19, 49-82.

STEVEN, J.-F. R., FOSSO WAMBA, S., AKTER, S. \& DUBEY, R. Forthcoming. Modelling Quality Dynamics, Business Value and Firm Performance in a Big Data Analytics Enivronment. Internal Journal of Production Research.

VARGO, S. L. \& LUSCH, R. F. 2004. Evolving to a New Dominant Logic for Marketing. Journal of Marketing, 68, 1-17.

VARGO, S. L. \& LUSCH, R. F. 2008. Service-dominant logic: continuing the evolution. Journal of the Academy of Marketing Science, 36, 1-10.

VENKATESH, V., THONG, J. Y. L., CHAN, F. K. Y., HU, P. J.-H. \& BROWN, S. A. 2011. Extending the twostage information systems continuance model: incorporating UTAUT predictors and the role of context. Information Systems Journal, 21, 527-555.

VERMA, R. \& BOYER, K. K. 2000. Service classification and management challenges. Journal of Business Strategies, 17, 5-24.

WAMBA, S. F., AKTER, S., EDWARDS, A., CHOPIN, G. \& GNANZOU, D. 2015. How 'big data' can make big impact: Findings from a systematic review and a longitudinal case study. International Journal of Production Economics, 165, 234-246.

WHITE, M. 2012. Digital workplaces: Vision and reality. Business Information Review, 29, 205-214.

WIELKI, J. 2015a. The opportunities and challenges connected with implementation of the big data concept.

WIELKI, J. 2015b. The social and ethical challenges connected with the big data phenomenon. Polish Journal of Management Studies, 11, 192-202.

WILDER, K. M., COLLIER, J. E. \& BARNES, D. C. 2014. Tailoring to Customers' Needs: Understanding How to Promote an Adaptive Service Experience With Frontline Employees. Journal of Service Research.

ZEITHAML, V. A., BITNER, M. J. \& GREMLER, D. D. 2012. Services Marketing - Integrating Customer Focus Across the Firm, McGraw-Hill Educaiton. 
$B D A$ n FLEs

Appendix-1: Literature Search Summary for Big Data and Frontline Employees 


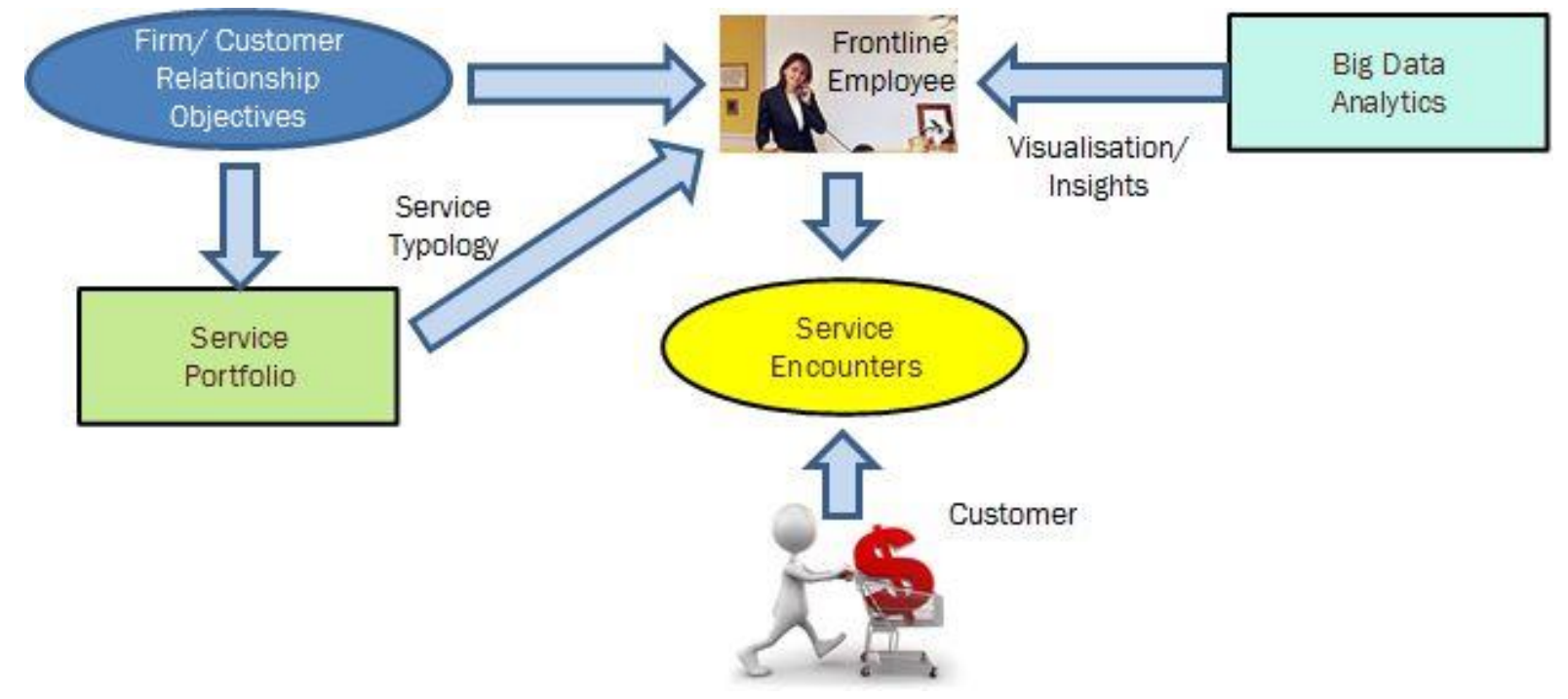

Figure-1: Big Data Analytics, Frontline Employees and Service Encounters 


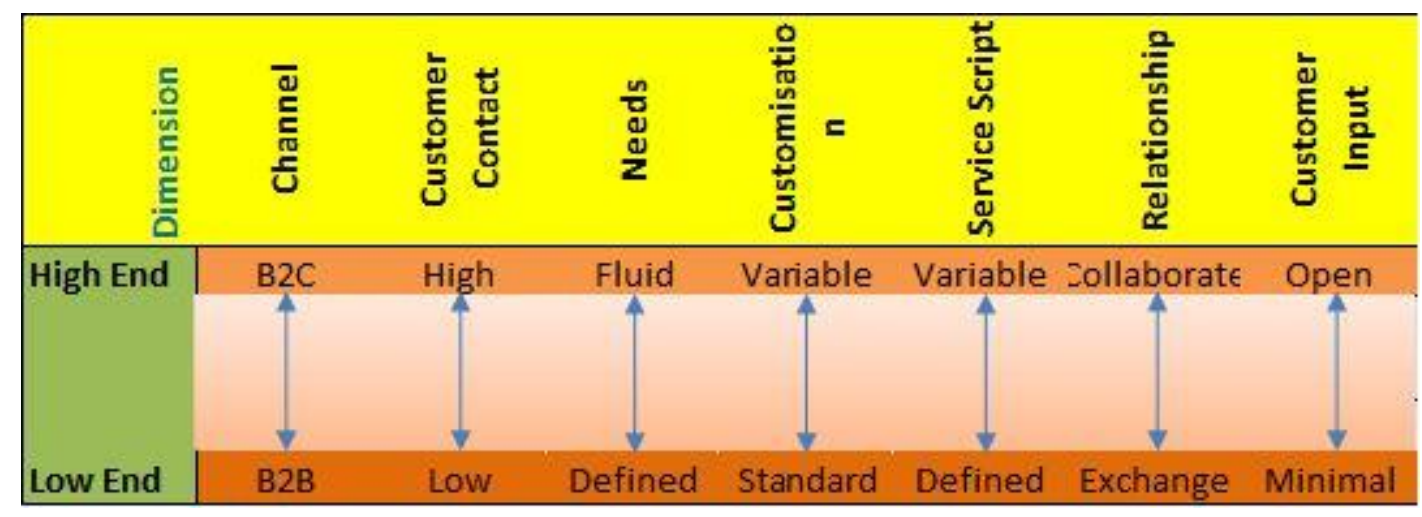

Figure-2a: Service Typology

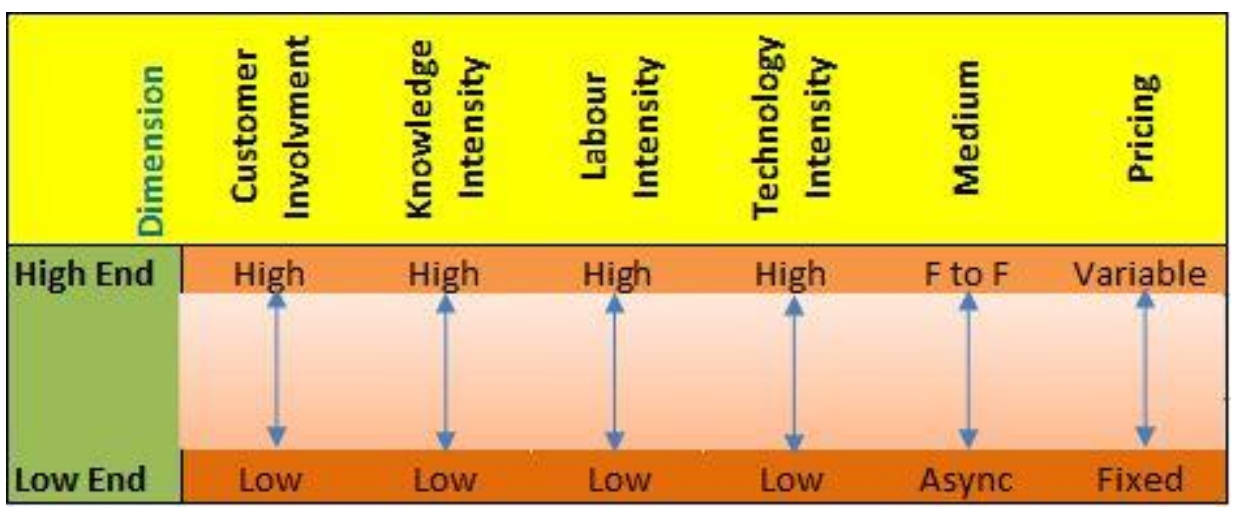

Figure-2b: Service Typology (contd.) 


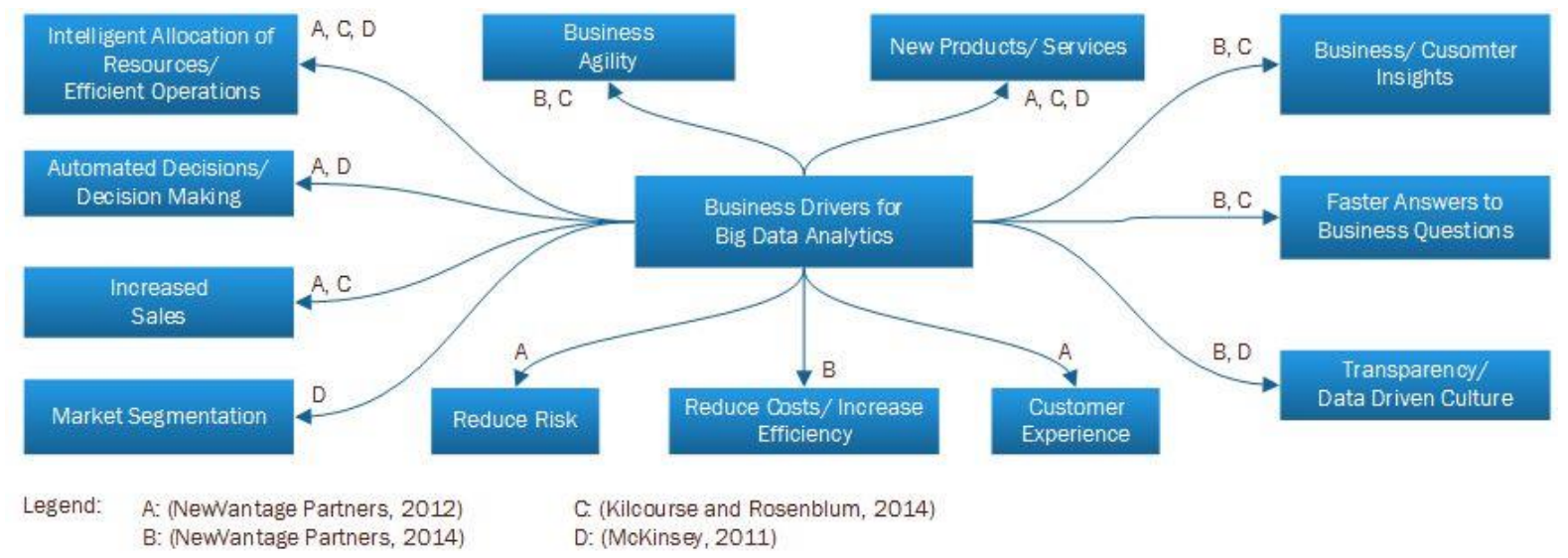

Figure-3: Primary Business Drivers/ Important Uses of Big Data 


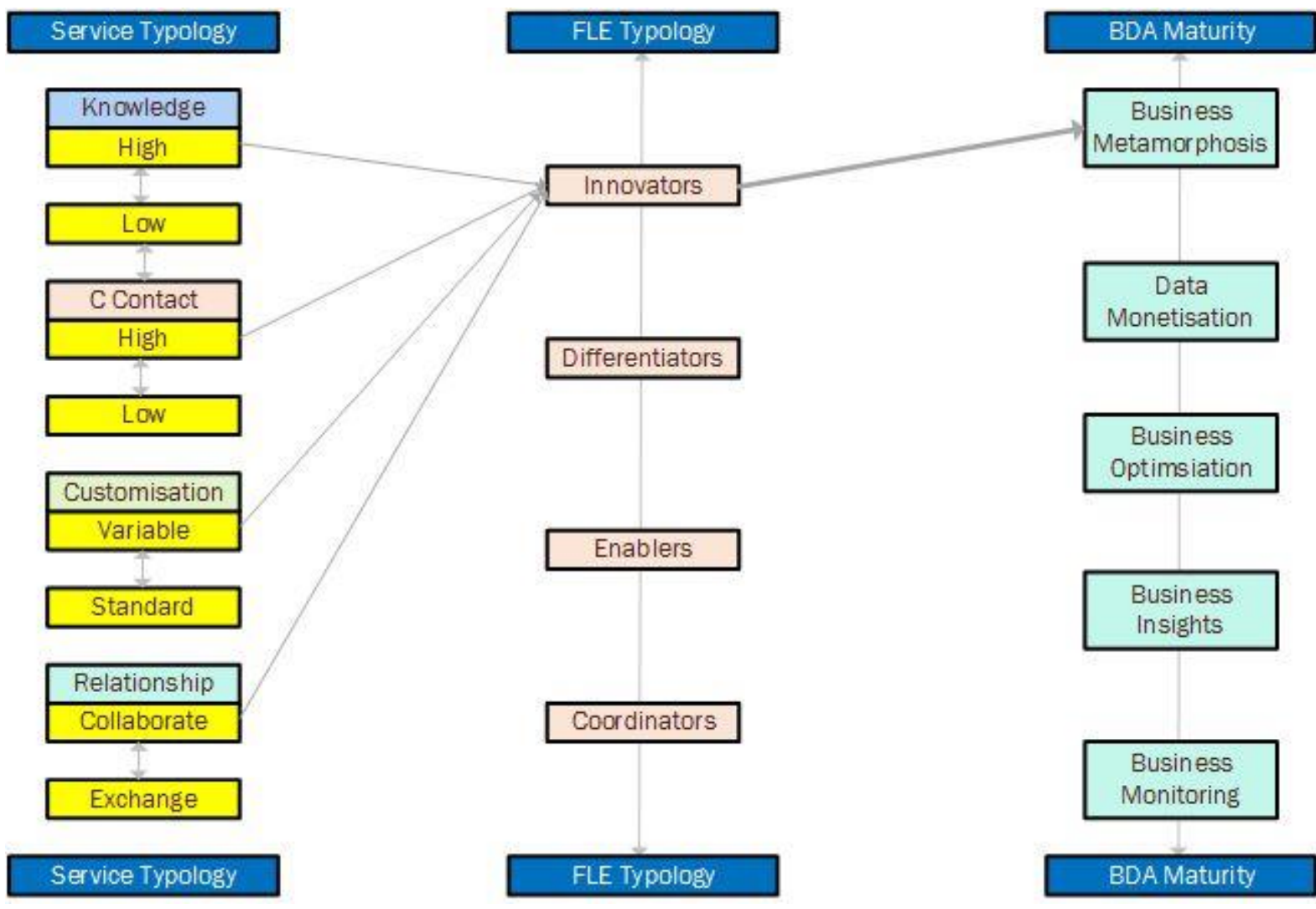

Figure-4: Interplay of Service, FLE Typologies and Big Data Analytics Maturity 
Table-1: Big Data Analytics Maturity Levels; Source (Schmarzo, 2012)

\begin{tabular}{|c|c|c|c|c|}
\hline $\begin{array}{l}\text { Business } \\
\text { Monitoring }\end{array}$ & $\begin{array}{l}\text { Business } \\
\text { Insights }\end{array}$ & $\begin{array}{l}\text { Business } \\
\text { Optimisation }\end{array}$ & $\begin{array}{l}\text { Data } \\
\text { Monetization }\end{array}$ & $\begin{array}{l}\text { Business } \\
\text { Metamorphosis }\end{array}$ \\
\hline $\begin{array}{l}\text { Monitoring } \\
\text { existing } \\
\text { business } \\
\text { performance } \\
\text { using BI to } \\
\text { identify under- } \\
\text { and over- } \\
\text { performing } \\
\text { business areas }\end{array}$ & $\begin{array}{l}\text { Users statistics, } \\
\text { predictive } \\
\text { analytics, and } \\
\text { data mining to } \\
\text { integrate } \\
\text { insights into } \\
\text { existing } \\
\text { business } \\
\text { processes }\end{array}$ & $\begin{array}{l}\text { Embedding } \\
\text { advanced } \\
\text { analytics to } \\
\text { automatically } \\
\text { optimise certain } \\
\text { business } \\
\text { operations }\end{array}$ & $\begin{array}{l}\text { Net new revenue } \\
\text { opportunities: } \\
\text { 1) selling data } \\
\text { with analytics } \\
\text { 2) creating } \\
\text { "intelligent" } \\
\text { products } \\
\text { 3) transforming } \\
\text { customer } \\
\text { relationships }\end{array}$ & $\begin{array}{l}\text { Transform } \\
\text { insights about } \\
\text { customers, } \\
\text { products, and } \\
\text { market trends to } \\
\text { create new } \\
\text { services and/ or } \\
\text { new markets }\end{array}$ \\
\hline
\end{tabular}


Appendix-1: Literature Search Summary for Big Data and Frontline Employees

\begin{tabular}{|c|c|c|c|c|}
\hline \multicolumn{2}{|c|}{ Search Theme } & \multirow{2}{*}{$\begin{array}{c}\text { Frontline Employees and Big Data } \\
\text { Search String }\end{array}$} & \multirow[b]{2}{*}{ Database } & \multirow[b]{2}{*}{ Results } \\
\hline Search \# & Date & & & \\
\hline 1 & $11-$ Nov-15 & "big data" & Scopus & 11,586 \\
\hline 1.1 & 11-Nov-15 & "service" & Scopus & 4,129 \\
\hline 1.2 & 11-Nov-15 & "front* employees" or "front* staff" & Scopus & 0 \\
\hline 1.3 & 11-Nov-15 & "frontline employees" & Scopus & 0 \\
\hline 1.4 & 11-Nov-15 & "frontline" & Scopus & 4 \\
\hline 1.5 & 11-Nov-15 & "front* employees" & Scopus & 0 \\
\hline 1.6 & 11-Nov-15 & "front* employees" or "front* staff" & Scopus & 0 \\
\hline 1.7 & $11-$ Nov-15 & "services" & Scopus & 4,129 \\
\hline 1.8 & 11-Nov-15 & "front line" or "front line" & Scopus & 11 \\
\hline 1.9 & 11-Nov-15 & "front line" or "front line" & Scopus & 24 \\
\hline 2 & 11-Nov-15 & "frontline employees" & Scopus & 369 \\
\hline 3 & 11-Nov-15 & "front* employees" & Scopus & 372 \\
\hline 4 & 11-Nov-15 & "front* and (employees or staff)" & Scopus & 0 \\
\hline 5 & 11-Nov-15 & "front* employees" or "front* staff" & Scopus & 774 \\
\hline 5.1 & 11-Nov-15 & "big data" & Scopus & 0 \\
\hline 5.2 & 12-Nov-15 & "service" & Scopus & 456 \\
\hline 5.3 & 12-Nov-15 & "challenges or problems or issues" & Scopus & 298 \\
\hline 6 & 11-Nov-15 & ("front* employees" or "front* staff") and "big data" & Scopus & 0 \\
\hline 7 & 11-Nov-15 & (front* employees or "front* staff") and service & Scopus & 456 \\
\hline 7.1 & 11-Nov-15 & "big data" & Scopus & 0 \\
\hline 8 & 13-Nov-15 & $\begin{array}{l}\text { (front* staff or employees or labor or personnel or } \\
\text { worker) or ("customer service" and (staff or } \\
\text { employee or personnel or labor or worker)) } \\
\text { "big data" or "analytics" or "data mining" or }\end{array}$ & Scopus & 729 \\
\hline 8.1 & 13-Nov-15 & "analysis" & Scopus & 66 \\
\hline 1 & 12-Nov-15 & "big data" & WOS & 5,024 \\
\hline 1.1 & 12-Nov-15 & $\begin{array}{l}\text { "big data" and service } \\
\text { ("big data") and service and (front* (employee or }\end{array}$ & WOS & 744 \\
\hline 1.2 & 12-Nov-15 & staff)) & WOS & 1 \\
\hline 1.3 & 12-Nov-15 & ("big data") and (front* (employee or staff)) & WOS & 1 \\
\hline 1.4 & 12-Nov-15 & ("big data") and (frontline employee) & WOS & 1 \\
\hline 21 & 23-Nov-15 & "customer service" & Scopus & 11,475 \\
\hline 21.1 & 23-Nov-15 & ("customer service") and (staff or employee) & Scopus & 1,809 \\
\hline 21.2 & 23-Nov-15 & "customer * staff" OR "customer * employee" & Scopus & 155 \\
\hline 21.3 & 23-Nov-15 & $\begin{array}{l}\text { "customer support staff" or "customer support } \\
\text { employee" }\end{array}$ & Scopus & 4 \\
\hline
\end{tabular}

